\title{
Remembering Markus Barth: A Biblical-Theological Existence
}

\section{An Introduction}

Markus Barth (1915-1994), eldest son of Karl and Nellie Barth, pursued his theological career along a path that took him from Switzerland to America and back again over the course of several decades. He and his wife, Rose Marie BarthOswald (1913-1993), whom he married in 1940, had five children. After studying theology at universities in Bern, Basel, Berlin, and Edinburgh, Markus served as Reformed pastor in the Swiss town of Bubendorf between 1940 and 1953. It was during this period that he earned a doctorate in New Testament from the University of Göttingen, graduating in 1947. Barth left congregational ministry in 1953 to pursue an academic career that saw him hold teaching posts in the U.S.A. first at the Presbyterian Theological Seminary at Dubuque, then at the University of Chicago, and finally at Pittsburgh Theological Seminary. During this time in America, Markus was actively involved in collaborating with others to establish the Karl Barth Society of North America. He returned to Switzerland in 1973 to take up the Chair in New Testament at the University of Basel, a post he held until his retirement in 1985 .

Markus Barth made signal and lasting contributions to Pauline scholarship and New Testament theology more generally, but he is also particularly well known for bringing his biblical scholarship to bear upon contemporary theological debates surrounding the implications of justification, the theology and practice of baptism and the Lord's Supper, and interfaith relations between Christians and Jews. Alongside his substantive published biblical commentaries - on Ephesians (1974), Colossians (1994) and Philemon (2000)stand both topical theological studies such as Die Taufe: Ein Sakrament? (1951), Rechtfertigung (1969, ET 1971), and Das Mahl des Herrn. Gemeinschaft mit Israel, mit Christus und unter den Gästen (1987, abridged ET 1988), and collections of essays on Jewish-Christian questions, including Israel and the Church (1969), DerJude Jesus, Israel und die Palästinenser (1975, ET 1978), and The People of God (1983).

Alert to the centenary of his birth in 2015, the Karl Barth Center of Princeton Theological Seminary — which curates Markus Barth's literary estate within the archives and special collections of the Seminary Library-worked to convene 
a research symposium to explore and debate the theological legacy of Markus Barth. The symposium took place in the autumn of 2018 and the six papers presented in this special issue of the Journal of Reformed Theology all have their origins in the lively discussions at the event: Joseph Small's personal reflections on Markus Barth as a theological teacher serve to introduce the man and sketch his theological profile. Subsequent essays explore his contribution to contested debates about the theology of baptism (MacLachlan) and the Lord's Supper (Nimmo). The remaining essays critically examine aspects of his engagement with questions of Jewish-Christian encounter, including its foundation in his interpretation of Ephesians as a mature Pauline letter (Ziegler), his oft-times difficult exchanges with contemporary Jewish thinkers, including Emil Fackenheim (Lindsay), and his conception and approach to Jewish-Christian dialogue and its limits (Rashkover). There is yet much instruction and provocation to be taken from fresh consideration of Markus Barth's life's work.

\author{
Philip G. Ziegler \\ University of Aberdeen, Aberdeen, Scotland, U K \\ p.ziegler@abdn.ac.uk
}

